\title{
Proposal for Development of Spatial Functions at Pre-school Age on the Basis of Neuropsychological Analysis of Graphic Activity
}

\author{
Yulia Solovieva \\ Luis Quintanar \\ Autonomous University of Tlaxcala, \\ Faculty of Sciences for Human Development, \\ Mexico, Tlaxcala
}

\section{Развитие пространственных функций у школьников на основе нейропсихологического анализа графической деятельности}

\author{
Юлия Соловьева \\ Луис Кинтанар \\ Автономный университет Тласкалы, \\ факультет наук о развитии человека, \\ Мексика, Тласкала \\ Corresponding author. E-mail:aveivolosailuy@gmail.com
}

\begin{abstract}
Child neuropsychology should be considered as a branch of general neuropsychology. Goals and tasks of child neuropsychology depend on a general psychological approach to the development. According to historical and cultural approach, neuropsychology as a science is directed not only towards assessing difficulties and establishing a diagnosis, but also towards creating methods for overcoming developmental problems and preventing such problems. Cultural and historical conception of development allows to study each psychological age according to a predominant type of child's activity. In case of pre-school age, the predominant activity is a role-play. This activity is extremely useful for child's development, but not enough for preparation to school. Play activity is performed in groups by communicative and precise material means (toys, objects and symbols). Another kind of useful activity is creative drawing as activity performed at a perceptive level and achieved by perceptive means. The aim of the article is to propose a way for introduction and gradual development of spatial orientation at a perceptive level within the content of original program for drawing. Neuropsychological analysis of drawing activity allows to specify brain mechanisms of the functional system of the action of drawing. The content of the functional system of the drawing action is presented together with the stages for introduction and formation of this action. The authors discuss
\end{abstract}


the usefulness of graphic activity for the development of spatial orientation at a perceptive level. Graphic activity should be broadly used in pre-school institutions as a basic method for formation of spatial analysis and synthesis and prevention of learning disabilities at school.

Keywords: spatial orientation; graphic activity; preschool development; child neuropsychology; developmental neuropsychology; prevention of learning disabilities.

Детская нейропсихология должна рассматриваться как раздел общей нейропсихологии. Цели и задачи детской нейропсихологии зависят от общепсихологического подхода к развитию ребенка. В соответствии с историко-культурологическим подходом нейропсихология как наука направлена не только на оценку трудностей и постановку диагноза, но и на создание методов преодоления проблем развития ребенка и предотвращения таких проблем. Культурно-историческая концепция развития позволяет изучать каждый психологический возраст в соответствии с преобладающим видом деятельности ребенка. В случае дошкольного возраста преобладающей деятельностью является игра. Это занятие чрезвычайно полезно для развития ребенка, но недостаточно для подготовки к школе. Игровая деятельность осуществляется в группах с помощью коммуникативных и конкретных материальных средств (игрушки, предметы и символы). Другим видом полезной деятельности является творческий рисунок. Это деятельность, осуществляемая на уровне восприятия и достигаемая средствами восприятия. Цель статьи - показать способ внедрения и постепенного развития пространственной ориентации на уровне восприятия в рамках содержания оригинальной программы для рисования. Нейропсихологический анализ изобразительной деятельности позволяет уточнить мозговые механизмы функциональной системы выполнения рисунка, а также этапы формирования изобразительной деятельности. Авторы обсуждают полезность графической деятельности для развития пространственной ориентации на уровне восприятия. Графическая деятельность должна широко использоваться в дошкольных учреждениях в качестве основного метода формирования пространственного анализа, синтеза и предотвращения нарушений при дальнейшем обучении в школе.

Ключевье слова: пространственная ориентация; графическая деятельность; дошкольное развитие; детская нейропсихология; нейропсихология развития; профитактика нарушений обучаемости.

\section{Introduction}

Neuropsychology is a branch of psychological science directed to identification and study of relation between psychological processes and their brain organization. Child neuropsychology offers a perspective of analysis of such relation in different periods of ontogenetic development. According to historical and cultural approach in neuropsychology, relation between psychological processes and brain organization differs according to child's predominant activity of each ontogenetic period. According to our opinion, neuropsychology should take into account diversity of cultural activities which are typical and useful for dif- 
ferent periods of ontogenetic development. These cultural activities conform the basis for consolidation of functional systems with broad amount of functional brain mechanisms. Each brain mechanisms should be included into meaningful actions within the process of collaboration an interaction guided by an adult.

Pre-school age is one of the specific ontogenetic periods, which possesses its own structure and content (Vigotsky, 1996). New psychological qualitative formations appear at the end of this period as new achievements of the age. Between them it's possible to mention such formations as voluntary activity, reflection, usage of signs and symbols, imagination and learning motivation (Salmina, 1988, 2013a; Davidov, 2000; Obukhova, 2006).

Vigotsky (2001) claimed that pre-school age is a sensitive period for acquisition of child's personality. This means that specific kinds of interaction between adult and child in groups of children should be organized during this period. Vigotsky, in his times, organized circles for reading, dramatization and performance for pre-school and schoolchildren. Communication with art is one of significant cultural experiences and conform the basis for further development of children (Vigotsky, 2001).

Communication with artistic means and expression might be accessible starting from the basic stage of preschool development. This stage starts at the age of three years old, as at this period children acquirer elementary language abilities, possibility to use toys, objects and simple substitutes of objects. Complex play activity includes in its own content actions of verbal and non-verbal communication, usage of toys and objects and further substitution of objects and actions by representative symbolic means (Salmina, 1988; Brédikyte, 2012; Solovieva \& Quintanar, 2013a). Complex forms of play with roles and rules was described as rector activity of pre-school age (Elkonin, 1989, 2016). Play activity serves as a platform for the development of voluntary activity and gradual formation of symbolic function (Solovieva, Gonzáles, \& Quintanar, 2016; Solovieva \& Gonzáles, 2016). Verbal development together with enrichment of variety of broad circle of communicative non-verbal and representative means emerge during child's participation in collective plays (Solovieva, López, \& Quintanar, 2015). Organization of dialogues in groups of children during plays helps for acquisition of regulative function of speech on external level as an important stage before passing on the level of inner speech (Vigotsky, 1995a; Escotto, 2011; Solovieva et al., 2015). As many psychological studies point out, the play is a powerful mean for development of imagination and self-regulation in pre-school children (Bredikyte \& Hakkarainen, 2017).

All these data clearly show the usefulness of new creative proposals for work with plays and game in pre-school institutions as a basic method for psychological development of activity and personality of children. At the same time, these methods serve also as the methods for prevention and correction of learning disabilities (Glozman, 2009; Soboleva, 2014a, 2014b, 2014c).

Nevertheless, neuropsychological analysis of learning disabilities at school age shows that play activity is not enough to guarantee positive functional development of brain mechanisms, which take part in the process of writing and reading. One of advantages of neuropsychological approach according to the theory of the structure and content of psychological actions is the possibility of analysis of brain mechanisms, which take part 
in each action at different levels. Luria (1998) gave example of neuropsychological analysis of writing as a functional system. In this publication, Luria wrote that the action of writing presents different levels of functioning at different period of learning at school. Writing at the beginning and at the end of primary school is different processes with different functional system. His followers continued the same line and studied with precision different mechanisms of this functional system (Akhutina \& Inshakova, 2008; Glozman, 2009).

It's important to stress that this point hasn't been perfectly understood and used in modern neuropsychology. The tendency to establish static and permanent localization of psychological functions in brain structures is still predominant in literature. This tendency reflects the aspiration to localize difficulties in school learning in same brain zones in all periods of school learning and to give same labels to pupils' difficulties with such terms as dyslexia and dysgraphia at all stages of school learning (DSM-5, American Psychiatric Association, 2014). According to Luria's conception of dynamic and systemic localization of superior psychological functions, the concepts of dyslexia and dysgraphia would at least not be same phenomenon in different periods of school learning.

According to Luria's conceptions, children might present difficulties in writing and reading due to broad variety of reasons. Between these reasons we may stress absence of functional preparation for school learning and also inappropriate methods of introduction of written language at school. Dependence of successful writing at school on organization of the process of learning and interaction between teacher and pupils in the third grade of primary school was studied in some previous publications (Solovieva, Torrado, \& Quintanar, 2018, 2019).

The goal of our study is to present neuropsychological analysis of graphic activity as the basis for design of effective methods for development of spatial analysis and synthesis as prevention and correction of developmental difficulties. The article is of methodological nature and presents qualitative results of the work with original method for gradual formation of drawing by stages (Solovieva \& Quintanar, 2016a). The article presents examples of qualitative experience of application of this method to pre-school children in private kinder garden in Mexico, organized and supervised by the authors of the article.

\section{Functional System of Graphic Activity}

Readiness for school might be studied according to psychological, socio-pedagogical aspects and neuropsychological aspects (Soboleva, 2014a). Psychological aspects refer to child's interest and motivation for learning, while socio-pedagogical aspects refer to adult's strategies and communication with the child. Neuropsychological aspects include functional readiness of essential elements of functional systems for reading and writing. Neuropsychological analysis of the structure and content of different kind of psychological actions may help for understanding of useful methods for development and prevention of learning disabilities at pre-school age. As a concrete example of such analysis we shall present analysis of functional system of writing as a kind of graphic activity. 
Both drawing and writing might be represented as two kinds of graphic activity. Vigotsky (1995b) has described children's drawing as previous history of writing. By his own part, Luria (1998) has always presented writing process as a clear example of complex functional system, which includes different functional components supported by various brain cortical zones. Such functional system doesn't exist in the brain at the beginning of development, but might be conformed according to participation of the subject in cultural activity. Considering importance of Luria analysis of functional system of writing, it's necessary to mention that broad participation of subcortical mechanisms takes part in graphic activity, when started from pre-school age.

We propose to consider drawing and writing processes as two types of graphic activity; this makes it possible to compare functional systems of both processes. Graphic activity includes the following essential aspects or functional operations:

- direction to previously established goal or anticipated image of graphic production with constant verification of the process and accordance with the model;

- organized sequential and precise hand movements with the usage of external mean (pen or pencil);

- spatial organization of lines on perceptive level.

The mentioned aspects or functional operations require a plenty of brain functional mechanisms at cortical and subcortical levels (see Table 1).

In case of writing, it's necessary to add operations or reflective actions of phonemic analysis of oral speech of each language in order to transform oral words into graphic representation. Functional system of writing is more complex in comparison with functional system of drawing, since it requires less quantity of functional elements. The Table 1 shows functional systems of drawing, while Table 2 show functional system of writing. According to activity theory, operations are automatic and semiconscious processes, while the actions are always directed to conscious goals of the subject. On different level of formation of each activity, both actions and operations might be accomplished by a subject. Initially, the subject starts acquisition of activity with conscious actions, which require complete functional system for each action. Later on, according to practice and the process of interiorization, actions pass to the level of automatized operations and the functional system reduces.

Table 1

Functional system of graphic activity: drawing

\begin{tabular}{ll}
\hline \multicolumn{1}{c}{ Actions / operations } & \multicolumn{1}{c}{ Neuropsychological mechanisms } \\
\hline $\begin{array}{l}\text { Direction/verification of the established goal } \\
\text { with observation or imagination }\end{array}$ & $\begin{array}{l}\text { Programming and control (possible } \\
\text { visual perception) and spatial functions } \\
\text { of a model for drawing }\end{array}$ \\
holistic \\
Organized hand movements & Spatial global perception \\
& Spatial analytic perception \\
& Motor kinetic organization \\
\hline
\end{tabular}


Table 1 (continued)

\begin{tabular}{ll}
\hline \multicolumn{1}{c}{ Actions / operations } & \multicolumn{1}{c}{ Neuropsychological mechanisms } \\
\hline Organization of image on perceptive & Motor kinestetic integration \\
Space & Spatial global perception \\
& Spatial analytic perception \\
& General brain activation \\
\hline
\end{tabular}

According to Table 1, spatial analysis and synthesis is one of essential functional elements of graphic activity, both of drawing and writing. The Table 2 presents the content of the functional system of graphic activity for the case of independent writing.

Table 2

Functional system of graphic activity: independent writing

\begin{tabular}{ll}
\hline \multicolumn{1}{c}{ Actions / operations } & \multicolumn{1}{c}{ Neuropsychological mechanisms } \\
\hline $\begin{array}{l}\text { Direction/verification of established idea/ } \\
\text { goal of writing production }\end{array}$ & $\begin{array}{l}\text { Programming and control of the goal } \\
\text { of writing }\end{array}$ \\
$\begin{array}{l}\text { Codification/decodificaiton of system } \\
\text { of sounds of language into system } \\
\text { of graphic representation }\end{array}$ & $\begin{array}{l}\text { Phonematic integration } \\
\text { Kinestetic integration } \\
\text { Organized hand movements }\end{array}$ \\
with the usage of external mean & Spatial global perception \\
& Spatial analytic perception \\
Organization of image on perceptive & Motor kinetic organization \\
space & $\begin{array}{l}\text { Motor kinestetic integration } \\
\text { Spatial global perception }\end{array}$ \\
Organization of grammar, morphology, & Spatial analytic perception \\
lexicon, semantic & General brain activation \\
& Programming and control \\
& Spatial analysis \\
& Motor kinetic organization \\
\hline
\end{tabular}

The Table 2 gives an approximate idea of complexity of functional system of the writing process. The aim of the article doesn't make it possible to discuss all mechanisms of writing process, because their participation depends on the level of grammar, morphological, lexical and meaning variety of written production and of personal goals of each subject of writing activity (Luria, 1998; Akhutina, 2002). Neuropsychological studies evidenced that difficulties in writing process might depend on poor level of functioning of spatial functions (Akhutina \& Zolotariova, 2007; Solovieva \& Quintanar, 2016b). According to literature, these functions include global strategy of perception of representations as unique images related mostly to right hemisphere and analytic strategy of perception of details and coordinates orientation related mostly to left hemisphere (Springer \& Deutsch, 1981). Different studies have detected impropriate development 
of concrete visual images at the end of pre-school age (Akhutina \& Pilayeva, 2003; Veraksa N.E. \& Veraksa A. N., 2012). Low level of development of spatial perception conduct to spatial confusion of letters, mathematic signs and digits at school. Problems with spatial orientation may become a cause of difficulties in written production and understanding of texts together with impossibility to interiorize structure of number and to solve properly mathematic problems (Akhutina \& Zolotariova, 2007). It is possible to say that functional deficit of spatial analysis and synthesis is one of neuropsychological reasons of diagnosis of dyslexia, dysgraphia and dyscalculia at school age (Akhutina \& Zolotariova, 2007; Akhutina \& Inshakova, 2008; Akhutina \& Pilayeva, 2012).

During the period of pre-school development, starting with the age of three years, it's rather difficult to separate these two strategies, so that both hemispheres work for both strategies of perceptive analysis and synthesis. That's why proper development of spatial functions and process of orientation at a perceptive level is one of central necessities of pre-school age.

\section{Description of Proposal for Introduction of Graphic Activity}

In order to guarantee successful development of spatial functions, they should be included in specific cultural actions of children. At the same time, these specific actions should not only be accessible for little children, but also should contribute to their psychological development. Constant repetition, work by unreflective simple reinforcement, adaptation or mechanic memorization are not the best actions to guarantee reflexive perception, thinking and creativity in pre-school children (Poddyakov, 2013). The actions chosen for work should correspond to the necessities of psychological age of children.

According to psychological content of pre-school age, drawing action results as the best choice for introduction of graphic activity. Specific features of pre-school age consist in predominant line of communicative and affective participation of a child in joint activity (Elkonin, 1989, 2016; Vigotsky, 1996). Table 3 resumes psychological feature of preschool age according to essential new formations of this ontogenetic period as indicators of positive preparation to school (Salmina, 2013b). In the present article, these psychological features are taken in consideration only in relation to importance for development of graphic activity. The authors are conscious that a lot of other important goals of development should be achieved in other kinds of pre-school activities such as play, artistic, physic and communicative activities (Bruce, Hakarainen, \& Brèdikyte, 2017; Veraksa N. \& Sheridan, 2018).

The Table 3 shows psychological features of pre-school age according to the concept of psychological age, including psychological new formations and content of significant actions.

According to Table 3, introduction of graphic activity at pre-school age should be based on the necessity of visual perception and analysis of concrete objects and images. At this age, children have to operate with enriched media of images and objects with a big variety of changeable and dynamic features such as shapes, colours, textures, details, spa- 
tial position of elements and shapes and so on. At the same time, these objects have to be functional cultural objects and not symbols and signs. The children have to recognise and use in their practical actions different cultural objects before they start to use and to create cultural symbols by themselves. Adults should guarantee emotional and affective positive involvement of children into practical and creative actions with objects and toys (Veraksa N.E. \& Veraksa A. N., 2012). Impossibility for differentiation of concrete objects and symbols may appear as one of the obstacles for development of complex symbolic functions and of understanding of the meaning of symbols at school age, which conduct to learning disabilities and problems in adaptation to school (Solovieva \& Quintanar, 2012a; Salmina, 2013b). All these considerations represent a solid base for proposal of specific method for introduction of drawing as the first type of graphic directed activity in child's life.

Table 3

Psychological feature of pre-school age

\begin{tabular}{ll}
\hline New psychological formations & \multicolumn{1}{c}{ Content of useful actions } \\
\hline Voluntary activity & $\begin{array}{l}\text { Present precise goals of each perceptive task with expla- } \\
\text { nation and orientation }\end{array}$ \\
Imagination & $\begin{array}{l}\text { Constant presentation of diversity of curiosity-provoking } \\
\text { perceptive models with explanation and orientation, } \\
\text { interesting and attractive models and tasks }\end{array}$ \\
Symbolic function & $\begin{array}{l}\text { Suggestions for multiple substitutions and representa- } \\
\text { tions with examples and orientation }\end{array}$ \\
Reflection & $\begin{array}{l}\text { Verbal comments and proposals for modification } \\
\text { of tasks and means during participation in tasks } \\
\text { in groups, emotional involvement in all tasks }\end{array}$ \\
\hline
\end{tabular}

The drawing should start with observations and operations of concrete images and objects instead of drawing of schemes, geometric figures or symbols, which represent no sense for little children.

We propose to start the work of introduction of graphic activity by drawing at the age of three year in groups in pre-school institutions. Our proposal is based on qualitative psychological and pedagogical experiment of introduction of graphic activity in small groups of children from the age of three years. We may call our proposal also as a variant of formative experiment in Vigotsky's and Gaperin's tradition, when the process of innovation of developmental practice consists in introduction and gradual formation of actions, which are absent in previous experience of participants (Galperin, 2002). The whole process implies elaboration of orientation base of action for specific action, which would conduct to formation of drawing activity. In order to identify such initial action for children it's necessary to analyse psychological operative and functional content of graphic activity. Operative content of activity helps to analyse the whole process, which has to be fulfilled by each participant of drawing activity. This content includes the following operations (based on Solovieva \& Quintanar, 2019a): 
1. Election of the object (external or internal model), which will be drawn.

2. Organization of the space on paper (surface) for representation of the shape of elected model.

3. Organization of the space on paper (surface) for representation of elements of elected model.

4. Determination of the general predominate shape of the object.

5. Election and disposition of the details of the objects.

6. Representation of the shape of object with the help of external shape.

7. Representation of specific details of the object.

8. Verification of the whole execution, comparison with the model, detection of errors, correction of errors.

According to Leontiev's conception of psychological activity, each action is directed to previously established goal. Later on, action might be reduced, automatized and converted into operation without necessity of reflective fulfilment (Leontiev, 1975, 1983). We use this methodological principal for our proposal of formation of graphic activity. At the very beginning, all mentioned operations represent independent actions of participants with conscious goal. The children require specific operative external help, including emotional support and orientation base of action. Additionally, children have to work firstly at level of material action, using attractive objects and toys.

Drawing activity, as we have previously mentioned, starts with establishment of the goal for drawing and continues with representation of organised lines properly organized on perceptive space (perceptive plan or level). The whole action of drawing is perceptive action, while children of three years old usually fulfil only concrete actions with objects and toys. Little children have strong difficulties for establishment of such a goal as they usually name their drawing after they produce some lines without specific shape and without differential features. Such first graphic productions aren't recognisable for children, their parents or teachers. Instead of waiting for "normal" and "natural" development of drawing and observe how later it will convert into writing and describe this "normal" process as followers of constructivism do, we prefer work with specific introduction of drawing by stages as follower of Galperin's conception of orientation (Galperin, 1998). According to this conception, orientation is the central object of psychological study, according to which success of activity depends on proper orientation. In case of pre-school children such orientation should be provided by adults.

In case of introduction of drawing activity, the specialist has to start on the level of actions with objects and toy and later pass to the level of creation of perceptive images in perceptive space. Such passing will be significant for development of child's spatial functions if conscious reflection of spatial features of images and their disposition on space would be included in this process. The model for reflective perception and analysis should be included at the first stage. Different stages and methodological considerations for orientation must be included into this process. 


\section{Stages of Introduction of Graphic Activity}

Our proposal finds strong arguments in the following theoretical and methodological psychological conceptions and of research data:

1. Relevant significance of spatial functions for cultural development, their relation to cognition, verbal and mathematic abilities (Luria, 1998).

2. Necessity of specific development of spatial functions in pre-school age (Akhutina \& Pilayeva, 2003) as prevention of learning disabilities.

3. Success in experimental groups and positive usage of formative experiment with graphic activity for developmental of spatial functions (Solovieva \& Quintanar, 2016c).

4. Cultural-historic paradigm of psychological development, which consider meaningful interaction between adult and child (Vigotsky, 1995a; Leontiev, 2000).

5. Theory of step-by-step formation of mental actions starting from external material level with possibility of passing to perceptive level of graphic actions (Galperin, 2000; Talizina, 2019).

6. Orientation base of action as the central element of content of new actions (Zaporozhets, 2000; Galperin, 2000; Solovieva, 2014).

The program includes four general stages (Solovieva \& Quintanar, 2016a; 2019b):

1. Previous stage (preparation of drawing), which implies work with material objects and toys, identification and analyses of all perceptive features, comparison of objects by features, corporal and perceptive symbolic representation of actions.

2. Drawing of independent objects according to the shape and external model, which implies introduction of representation of objects based on observation of models (objects and concrete images), analysis of features, identification of basic shapes.

3. Drawing of objects with enriched features according to internal model, which includes analyses of features, representation of shapes and details of perceptive models.

4. Drawing of situations ("illustrations for fairy tales" or "landscapes") according to external or internal (imaginative) model, proposed and created by participants.

All actions were fulfilled in groups of children by constant verbal orientation of adult. The sessions were organized by teachers on the basis of emotional involvement of children in collective activity.

\section{Results and Discussion}

The process of child's development depends on the organization and selection of activities, in which the child takes part during this period of development. Pre-school institutions frequently chose tasks and activities empirically without any justification from psychological point of view (Salmina, 2013a, 2013b; Obukhova, 2006). 
Recently, the ways of design of the methods for prevention and correction of difficulties in future school learning has become one of new points of attention for developmental psychologists and neuropsychologists (Solovieva \& Quintanar, 2016a, 2017a). Creation and introduction of new methods for psychological development might show new paths for early education. Our proposal consists in initial introduction of joint actions of drawing from the very beginning (Solovieva \& Quintanar, 2016b).

The stages of our proposal for introduction and development of graphic activity at pre-school age are used in private Kinder Garden (Kepler College) in the city of Puebla, in Mexico. The whole work of this college is organized in the basis of activity theory applied to the process of education (Talizina, 2019). Pre-school development include participation in guided play activity (Solovieva \& Quintanar, 2017b, 2019a, 2019b), work with understanding and interpretation of fairy tales and formation of graphic activity by stages. Formation of graphic activity take place in groups of pre-school children from three to six years old respectively in groups of first, second and third level of pre-school education. The number of children varies from 4 to 10 participants in groups each year.

Results of progress in graphic activity are qualitatively different at each level of preschool development. At the first year of pre-school development it's possible to achieve simple representation of global shape of concrete objects by children. At the second grade of pre-school education the children may introduce specific details into their representations. During the third year of work, children start to propose and create their own imaginative models of complex situations according to the content of tales and stories, according to examples of landscapes and external models for picturesque situations. The following examples show achievements of the children in diverse groups each year of pre-school education.

Examples of drawing produced by pre-school children from three to six years old are presented below. All children were pupils of Kepler College of 1st, 2nd and 3rd grades of preschool educational. Children worked with the program every day for one session of 50 minutes approximately.

On the first stage children from the first grade of pre-school education worked with external shapes, representation of movement of objects by gestures and initial drawing of lines with sense. Natural phenomenon as raining and clouds helped children to imagine lines with sense and represent them properly on the paper. Example 1 shows the task completed by a child of three years old. An adult prepared the "clouds" and the child continued with the "rain" (all photographs are courtesy of Kepler College).

Example 1. Representation of vertical lines. "Raining" (see Figure 1).

On the second stage children from the second grade of pre-school education managed to produce simple concrete objects by using curve lines and points. External material or perceptive models were always used on this stage. The teacher oriented the children with oral speech and explanation of all details of each object (example 2). 

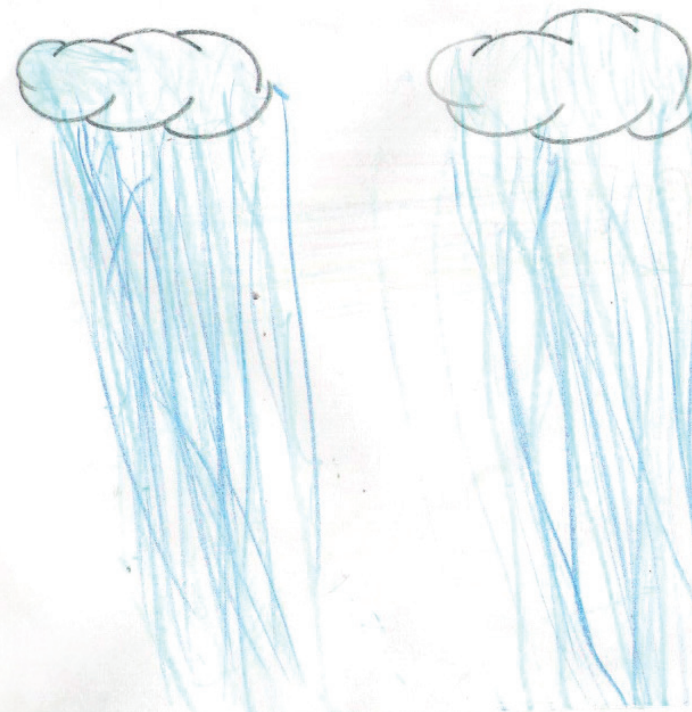

Figure 1. "Raining". Clouds are drawn by teacher and the child only adds the lines for "raining"

Example 2 shows the drawing of a child from the second grade - drawing of elephant by model $^{1}$ (see Figure 2).

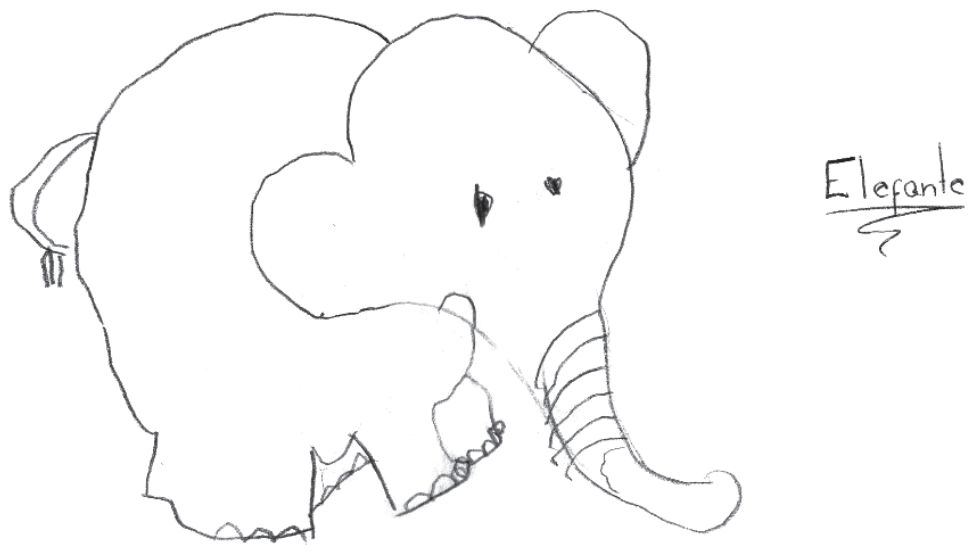

Figure 2. "An elephant"

On the third stage children from the third grade of pre-school education managed to produce complex objects by using curve lines and differential spatial relations. The context of fairy tales was frequently used in order to provide orientation and impulse imaginations of children. The teacher also tried to make own picture on board as an example for children. The teacher oriented children with oral speech and explanation of all details

1 The teacher wrote the word "elephant" on the drawing of the child. 
of each image. The children added own details and features to the drawings. Complex spatial relation appeared on this level (example 3).

Example 3 present lovely work if the child the third grade, who managed to draw this Little Siren under the water according to well-known tale by H. Ch. Andersen (see Figure 3).

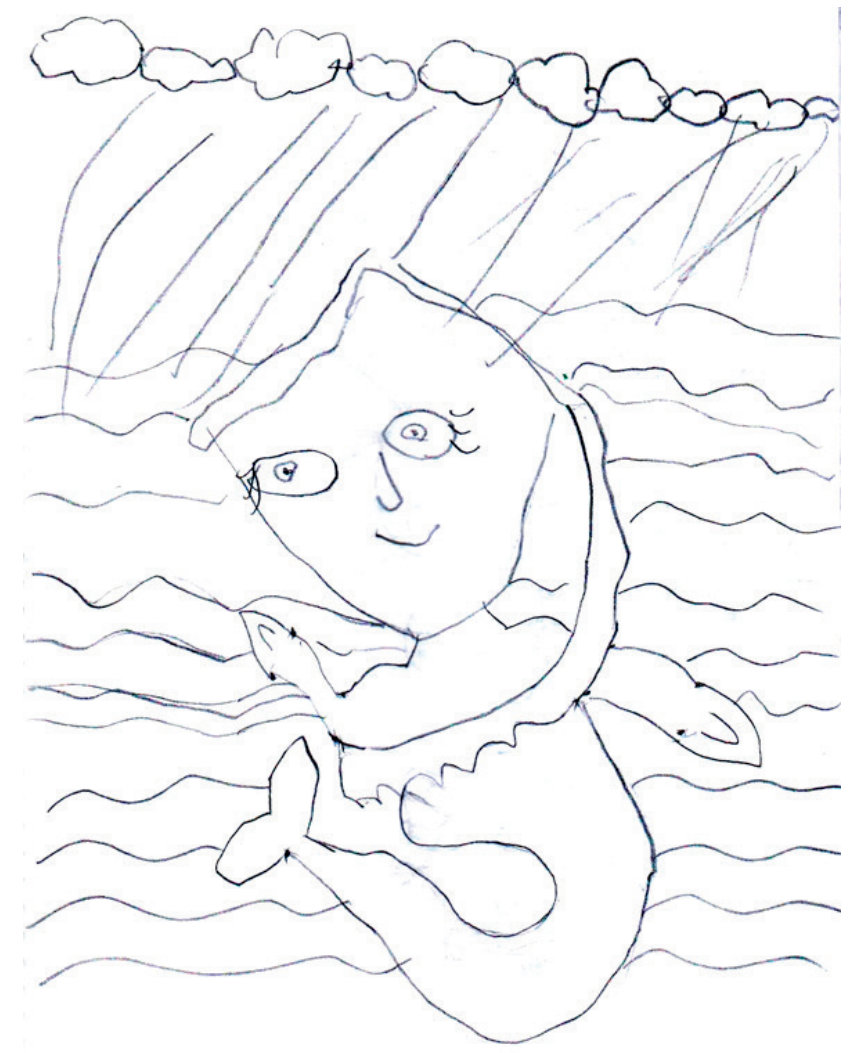

Figure 3. "Little Siren under the water"

On the fourth stage children from the third grade (last three months) started to construct own examples of complex situations with spatial orientation of each element with the help of toys, objects, symbols and marks (town, village, zoo, forest and so no). Examples of illustration of landscapes and photographs were used as examples in order to provide orientation to this activity. The teacher took part in all propositions and constructions of situations. The children added differential details to the drawings of complex situations. Complex spatial relation showed pronounced development at this stage (example 4).

Example 4 shows complex drawing of the child from the third grade who managed to present the street with symbolic means for direction of the traffic (see Figure 4). 


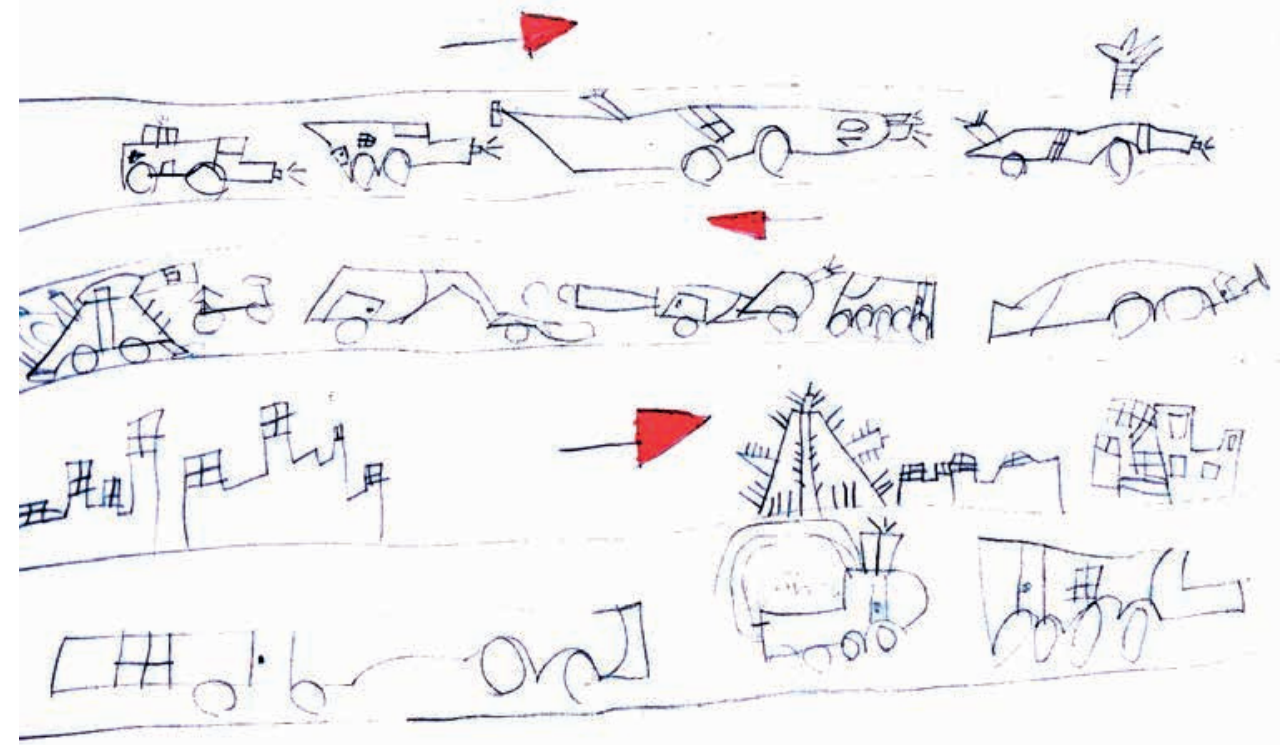

Figure 4. "Traffic in the streets of the town"

These examples show the progress in children's ability to represent models on perceptive space. Such tasks include both aspects of global and analytic perception, which involve both brain hemispheres according to neuropsychological research (Springer \& Deutsch, 1981). Neuropsychological assessment of spatial functions commonly uses drawing tests. These tests might represent abstract models or concrete models (Luria, 1973; Akhutina \& Pilayeva, 2012; Solovieva \& Quintanar, 2017). Such tests detect serious difficulties of holistic and analytic strategies in children with learning disabilities and adults with brain damage. Difficulties might be found in production of independent drawing by instruction and in tasks for copy of different objects by young children with low level of development of spatial functions (Glozman, 2009; Akhutina \& Pilayeva, 2012; Soboleva, 2014b; Solovieva \& Quintanar, 2016c).

Different kind of mistakes are related to functional deficit of left and right hemisphere. Adult patients with posterior brain lesions also show specific difficulties in holistic (related to dysfunction of right hemisphere), analytic perception (related to dysfunction of left hemisphere) or both strategies of perception (both hemispheres).

According to the data of difficulties of adults with posterior brain damage, detected specifically in drawing tasks and similar difficulties in little children who aren't able to follow tasks of graphic activity, it's logic to suppose that guided introduction and formation of graphic activity by levels might help both processes of development in children and rehabilitation in adults and adolescents (Solovieva \& Quintanar, 2017b, 2018a, 2018b). Our results show positive effect of development of drawing activity in children (Solovieva \& Quintanar, 2017b). Some previous original research permits to conclude that work with 
drawing is useful method for neuropsychological rehabilitation of adults and adolescents with posterior brain damage.

One of our studies showed how drawing tasks helped for rehabilitation of spatial analysis and synthesis in adult patient with semantic aphasia (Solovieva \& Quintanar, 2018b). The patient was systematically trained to use own reflection for analysis of relation between details in objects and representations. This work shows how the tasks with established goals for drawing activity help to re-establish spatial functions of analytic perception. Another study shows how drawing tasks helped for re-establishment of global perception in a left-handed patient with brain damage in left hemisphere (Solovieva \& Quintanar, 2018c). In this case, reflection of the patient was directed to production of global shaped of objects and symbols by stages. Same tasks directed to reflective identification of shapes and spatial representation of details in representations helped in case of rehabilitation of adult with brain damage by stoke in right hemisphere (Solovieva, López-Cortés, \& Rosas-Alvares, 2018).

These examples illustrate that spatial functions might be introduced, development and re-established by presentation of specific guided orientation with conscious goals of analysis and synthesis of representation. Graphic conscious activity represents ideal context for establishment of such goals for children and adults.

The stages of work with graphic activity show the usefulness of orientation for development of spatial functions (Solovieva \& Quintanar, 2017b). These stages help to create orientation for realization of the actions of representation by gestures and concrete actions as the basis for later orientation on the level of graphic space. Production of lines and global shapes is the start point of drawing activity. Later on, children became able to produce objects with plenty of specific features. At the final stage, individual imaginative models became accessible for children.

We believe that our work with introduction of graphic activity has stretch relation with the way how Luria understood the process of children's development at pre-school age. His own research of this topic directed to formation of creative construction tasks in groups of pre-school children determined that specific orientation and quality of materials for construction lead to better orientation in presented models. Children who were allowed to use complex elements and shapes with guided orientation showed better results in final tests for constructive activity (Luria, 2013). Our study is of the same spirit of great possibility and effectiveness of proper cultural development, which shows that spatial functions might be formed within graphic activity. Such functions don't appear "naturally" only according to maturation of brain cortical zones.

In "normal" conditions, the level of acquisition of graphic abilities is very low in Mexican pre-scholars together with low level of symbolic development (Solovieva \& Quintanar, 2013a). Low level of graphic activity corresponds to low level of spatial functions and possible learning disabilities, especially in acquisition of writing and reading (Solovieva \& Quintanar, 2016c).

According to historical and cultural conception of psychological development and activity theory, it's possible to introduce and to guide the children in their activities. In our research, we propose to start formation of graphic activity on material level of concrete 
objects, so that the child may identify consciously all features of the objects. The shape is introduced as one of the feature, that is essential for drawing process. The introduction of graphic activity starts by representation of shapes and movements by gestures, actions with objects and identification of external shapes of objects by usage of models of shapes (Solovieva \& Quintanar, 2012b, 2013b, 2016b). Later, perceptive work starts, which has a positive effect of development of spatial functions. Perception and production of lines and shapes is initial stage of graphic representation. Materialized orientation is presented all the time on order to facilitate identification of shapes in real and perceptive objects (Salmina \& Glebova, 2005a, 2005b; Salmina, 2009). Before the program all children have shown absence of developed drawing activity. After program application, all children showed qualitative positive achievements in graphic activity such as spatial global and analytic orientation, essential features and shapes of represented objects.

The election of the content of the tasks used during introduction of graphic activity points out the necessity of precise actions of the child. Such actions might be detected on the basis of analysis of functional system of graphic activity at different levels: level of drawing of objects and level of writing. Each level has to be introduced and formed as guided activity of the child by an adult or of the patient by neuropsychologist.

The present article described effective procedures for introduction and development of spatial functions within the context of graphic activity. Future studies might show the possibility of the work with other components of functional system during development and rehabilitation. Neuropsychology, as a branch of psychology based on general activity theory should be directed to innovations in education and treatment of functional difficulties in children and adults.

\section{Conclusions}

Analysis of the functional system of graphic activity allows to detect one of the central functional elements of this activity: spatial functions. Psychological analysis of the content of this activity permits to identify initial action of representation as the first stage for introduction of this activity. The article has presented the stages and procedure of formation of graphic activity in groups of pre-school children. The way for formation and rehabilitation of spatial functions within meaningful cultural actions of drawing as original method for development and rehabilitation was presented.

The stages of the proposed method are the following: the stage of preparation for drawing on a material level; the stage of drawing of independent objects on the basis of materialized orientation and according to external material models; drawing of objects with enriched features according to perceptive and internal model and, finally, drawing of situations according to external or imaginative models.

Future research might be directed towards precise modification of the method for cases of developmental difficulties, learning disabilities in primary school and proposal of methodological adaptation for adults and adolescents with acquired brain injury. 


\section{References}

Akhutina, T. V. (2002). Neuropsychological analysis of dynamic aphasia. Moscow: Terevinf. [In Russian] Akhutina, T. V., \& Inshakova, O. B. (2008). Neuropsychological diagnosis and assessment of writing and reading in pupils of primary school. Moscow: Creative Center V. Sekachev. [In Russian]

Akhutina, T. V., \& Pilayeva, N. M. (2003). Diagnosis and development of visual verbal functions. Moscow: Academia. [In Russian]

Akhutina, T. V., \& Pilayeva, N.M. (2012). Overcoming learning disabilities. A Vigotskian-Lurian neuropsychological approach. Cambridge: Cambridge University Press.

Akhutina, T.V., \& Zolotariova, E. V. (2007). Acerca de la disgrafia visuo-espacial: Análisis neuropsicológico y métodos de corrección [About visuo-spatial dysgraphia: Neuropsychological analysis and methods for correction]. In L. Quintanar \& Yu. Solovieva (Eds.), Métodos de intervención en la neuropsicológica infantil [Methods for intervention in child neyropsychology] (pp. 39-46). Mexico: Puebla Autonomous University.

American Psychiatric Association (2014). Guía de consulta de los criterios diagnósticos del DSM-5 [Spanish edition of the desk reference to the diagnostic criteria from DSM-5]. American Psychiatric Pub. Bredikyte, M. (2012). The act of cultural mediation in children's play. Forum Oświatowe, 2 (47), 81-100. Brèdikyte, M., \& Hakkarainen, P. (2017). Self-regulation and narrative intervention in children's play. In T. Bruce, P. Hakarainen, \& M. Brèdikytė (Eds.), The Routledge International handbook of early childhood play (pp. 246-258). London: Taylor \& Francis.

Bruce, T., Hakarainen, P., \& Brèdikytè, M. (2017). The Routledge International handbook of early childhood play. London: Taylor \& Francis.

Davidov, V.V. (2000). Types of generalization in teaching. Moscow: Pedagogical Society of Russia. [In Russian]

Elkonin, D. B. (1989). Selected psychological works. Moscow: Pedagogy. [In Russian]

Elkonin, D. B. (2016). Hacia el problema de periodización del desarrollo en la edad infantil [The problem of periodization of development in infancy]. In Yu. Solovieva \& L. Quintanar (Eds.), Las funciones psicológicas en el desarrollo del niño [Psychological functions in child's development] (pp. 191-209). Mexico: Trillas.

Escotto, A. (2011). El lenguaje interno como discurso dialógico y polifónico: estudio de caso [Inner speech as dialogical and polyphonic discures]. Revista CES Psicología, 4 (2), 72-83.

Galperin, P. Ya. (1998). Psychological activity as objective science. Moscow: Institute of Pedagogical and Social Sciences. [In Russian]

Galperin, P. Ya. (2000). Psychology: Four conferences. Moscow: Superior School. [In Russian]

Galperin, P. Ya. (2002). Introduction to psychology. Moscow: Superior School. [In Russian]

Glozman, J. (2009). Neuropsychology of childhood. Moscow: Academia. [In Russian]

Leontiev, A. N. (1975). Activity, consciousness, personality. Moscow: Moscow State University. [In Russian]

Leontiev, A. N. (1983). Selected works. Moscow: Moscow State University. [In Russian]

Leontiev, A. N. (2000). Conferences on general psychology. Moscow: Smysl. [In Russian]

Luria, A. R. (1973). Bases of neuropsychology. Moscow: Moscow State University. [In Russian]

Luria, A. R. (1998). Language and consciousness. Rostov-na-Donu: Feniks. [In Russian] 
Luria, A. R. (2013). Desarrollo de actividades constructivas en edad preescolar [Development of constructive activity at preschool age]. In Yu. Solovieva \& L. Quintanar (Eds.), Antología del desarrollo psicológico del niño en la edad preescolar [Handbook on psychological development in pre-school age] (pp. 138-167). Mexico: Trillas.

Obukhova, L. F. (2006). Psychology of development. Moscow: Superior Education. [In Russian]

Poddyakov, N. N. (2013). Sobre el problema del desarrollo intelectual en el niño [On the problem of intellectual development in child]. In Yu. Solovieva \& L. Quintanar (Eds.), Antología del desarrollo psicológico del niño en la edad preescolar (Handbook on psychological development in pre-school age] (pp. 27-29). Mexico: Trillas.

Salmina, N. G. (1988). Sign and symbol in education. Moscow: Moscow State University. [In Russian]

Salmina, N. G. (2009). Learning to think (Pt. 1, 2). Moscow: Ventana-Graf. [In Russian]

Salmina, N. G. (2013a). La funcción semiótica y el desarrollo intelectual [Semiotic function and intelectual development]. In Yu. Solovieva, \& L. Quintanar (Eds.), Antología del desarrollo psicológico del niño en la edad preescolar [Handbook on psychological development in pre-school age] (pp. 75-86). Mexico: Trillas.

Salmina, N. G. (2013b). Indicadores de la preparación de los niños para la escuela [Indicators of preparation of children for school]. In Yu. Solovieva \& L. Quintanar (Eds.), Antología del desarrollo psicológico del niño en la edad preescolar [Handbook on psychological development in pre-school age] (pp. 67-74). Mexico: Trillas.

Salmina, N. G., \& Glebova, A. O. (2005a). Learning to draw. Analysis of shapes and creation of images. Moscow: Ventana-Graf. [In Russian]

Salmina, N. G., \& Glebova, A. O. (2005b). Learning to draw. Lines and shapes. Moscow: Ventana-Graf. [In Russian]

Soboleva, A.E. (2014a). How to teach a child to read. St. Petersburg: Detstvo-Press. [In Russian]

Soboleva, A.E. (2014b). How to prepare a child to study writing. St. Petersburg: Detstvo-Press. [In Russian]

Soboleva, A.E. (2014c). How to prepare a child for learning of mathematics. St. Petersburg: Detstvo-Press. [In Russian]

Solovieva, Yu. (2014). La actividad intelectual en el paradigma histórico-cultural [Intellectual activity according to cultural-historical paradigm]. Mexico: CEIDE.

Solovieva, Yu., \& Gonzáles, C. (2016). Indicadores de la adquisición de la función simbólica en el nivel de acciones verbales en preescolares [Indicators of acquisition of symbolic functions on the level of verbal actions in pre-scholars]. Revista de la Facultad de Medicina, 64, 2, 257-265.

Solovieva, Yu., Gonzáles, C., \& Quintanar, L. (2016). Developmental analysis of symbolic perceptual actions in preschools. British Journal of Education, Society and Behavioural Science, 15, 3, 1-13.

Solovieva, Yu., López, A., \& Quintanar, L. (2015). Formación de la función mediatizadora del lenguaje a través del análisis de cuentos en preescolares [Formation of function of mediatization of language by analysis of tales in pres-scholars]. Revista Educacao em Questao, 52, 38, 11-35.

Solovieva, Yu., López-Cortés, V.A., \& Rosas-Alvares, D. (2018). Neuropsychological rehabilitation of right brain injury: A case report. International Neuropsychiatric Disease Journal, 12, 1, 1-15.

Solovieva, Yu., \& Quintanar, L. (2012a). Actividad de juego en la edad preescolar [Play activity in preschool age]. México: Trillas. 
Solovieva, Yu., \& Quintanar, L. (2012b). Formation of drawing activity in Mexican preschool children. Psychology Research, 2, 8, 479-489.

Solovieva, Yu., \& Quintanar, L. (2013a). Evaluación del desarrollo simbólico en niños preescolares mexicanos [Assessment of symbolic development in Mexican preschool children]. Cultura y Educación, 25, 2, 167-182.

Solovieva, Yu., \& Quintanar, L. (2013b). Importance of drawing development in preschool age. Preschool Education Today, 1, 80-84.

Solovieva, Yu., \& Quintanar, L. (2016a). El dibujo como actividad formativa en la edad preescolar [The drawing as formative activity in preschool age]. Mexico: Trillas.

Solovieva, Yu., \& Quintanar, L. (2016b). The role of zone of proximate development in interactive assessment of intellectual development. British Journal of Education, Society and Behavioural Science, 14, 1, 1-11.

Solovieva, Yu., \& Quintanar, L. (2016c). Educación neuropsicológica infantil [Education and child neuropsychology]. Mexico: Trillas.

Solovieva, Yu., \& Quintanar, L. (2017a). Stages for introduction of drawing actions in pre-school age. Journal of Education and Culture Studies, 1, 12-24.

Solovieva, Yu., \& Quintanar, L. (2017b). Organization of playing activity at preschool age. In T. Bruce, P. Hakarainen, \& M. Bredikyte (Eds.), The Routledge International handbook of early childhood play (pp. 340-354). London: Taylor \& Francis.

Solovieva, Yu., \& Quintanar, L. (2017c). Evaluación neuropsicológica infantil breve Puebla. ENIB-Puebla [Brief neuropsychological assessment for children Puebla. ENIB-Puebla]. Mexico: Autonomous University of Puebla.

Solovieva, Yu., \& Quintanar, L. (2018a). Luria's syndrome analysis for neuropsychological assessment and rehabilitation. Psychology in Russia: State of the Art, 11, 2, 81-99.

Solovieva, Yu., \& Quintanar, L. (2018b). Rehabilitation of semantic aphasia in Spanish-speaking patient. Psychology in Russia: State of the Art, 11, 1, 137-150.

Solovieva, Yu., \& Quintanar, L. (2018c). Neuropsychological rehabilitation in a case of dynamic aphasia. International Neuropsychiatric Disease Journal, 11, 4, 1-15.

Solovieva, Yu., \& Quintanar, L. (2019a). Playing activity with orientation as a method for preschool development. Psychological Educational Studies, 11, 4, 49-66.

Solovieva, Yu., \& Quintanar, L. (2019b). Progressive work with drawing in groups of preschool children in Mexico and Colombia. Perspectives of Arts and Social Science, 2, 145-158.

Solovieva Yu., Torrado O., \& Quintanar L. (2018). Orientation for initial introduction of written speeach in primary school. Journal of Education, Society and Behavioural Science, 24 (4), 1-18.

Solovieva, Yu., Torrado, O., \& Quintanar, L. (2019). Learning of reading and writing in primary school: A method of reflective and conscious analysis of words. Perspectives of Arts and Social Science, 2, 80-104.

Springer, S. P., \& Deutsch, G. (1981). Left brain. Right brain. San Francisco \& London: W. H. Freemont \& Company.

Talizina, N. F. (2019). La teoría de la actividad aplicada a la enseñanza [Activity theory applied for learning]. Mexico: Universidad Autónoma de Puebla. 
Veraksa, N., \& Sheridan, S. (2018). Vygotsky's theory in early childhood education and research. London: EECERA, The Routledge: Taylor \& Francis.

Veraksa, N.E., \& Veraksa, A. N. (2012). Cognitive development in preschool age. Moscow: MOSAIC-SYNTHESIS. [In Russian]

Vigotsky, L.S. (1995a). Obras escogidas: Tomo 3. Desarrollo del lenguaje oral [Selected works: Vol. 3. Development of oral speech] (pp. 169-182). Madrid: Visor.

Vigotsky, L.S. (1995b). Obras escogidas: Tomo 3. La prehistoria del desarrollo del lenguaje escrito [Selected works: Vol. 3. Pre-history of development of written speech] (pp. 183-206). Madrid: Visor. Vigotsky, L. S. (1996). Obras escogidas: Tomo 4 [Selected works: Vol. 4]. Madrid: Visor.

Vigotsky, L.S. (2001). La imaginación y el arte en la infancia [Imagination and art in infancy]. Mexico: Ediciones Coyoacán. Psicología.

Zaporozhets, A. V. (2000). Psychology of action. Moscow: Academy of Pedagogical and Social Sciences. [In Russian]

Original manuscript received February 3, 2020 Revised manuscript accepted March 19, 2020

To cite this article: Solovieva, Yu., \& Quintanar, L. (2020). Proposal for development of spatial functions at pre-school age on the basis of neuropsychological analysis of graphic activity. Lurian Journal, 1 (1), 109-128. DOI:10.15826/Lurian.2020.1.1.8 